\title{
Omega-3 fatty acids induce biochemical changes in the small bowel of rats before and after resection
}

\author{
João Carlos Nunes de Oliveira', Clarice Izumi ${ }^{2}$, Sergio Zucoloto ${ }^{3}$, Arony Aparecido Lopes ${ }^{1}$, \\ Camila Alves Areda ${ }^{1}$, Osvaldo de Freitas ${ }^{1 *}$
}

${ }^{1}$ Departamento de Ciências Farmacêuticas, Faculdade de Ciências Farmacêuticas de Ribeirão Preto, Universidade de São Paulo, ${ }^{2}$ Centro de Química de Proteínas, ${ }^{3}$ Departamento de Patologia, Faculdade de Medicina de Ribeirão

Preto, Universidade de São Paulo

*Correspondence:

O. Freitas

Departamento de Ciências

Farmacêuticas, Faculdade de Ciências

Farmacêuticas de Ribeirão Preto

Universidade de São Paulo

Av. do Café s/n,

14040-903, Ribeirão Preto, SP, Brazil

E-mail: ofreitas@fcfrp.usp.br
In the present study, the effect of dietary fish oil, a highly unsaturated fat source, on the intestinal mucosa before and after proximal small bowel resection in rats was studied. Forty Wistar rats were fed defined diets containing fish oil (experimental group) or corn oil (control group). After 2 weeks, animals underwent a $50 \%$ proximal small bowel resection. Mucosal disaccharidases, alkaline phosphatase, aminopeptidase, protein, DNA, and TBARs levels were assessed in samples immediately before and 6 and 12 days after surgery. Disaccharidase activities were reduced in the ileal mucosa from rats in the fish oil-fed group compared to the control group before and 12 days after surgery. The other parameters showed no significant differences. The results indicate that fish oil (omega-3 fatty acids) alters the functional parameters of the normal intestinal mucosa and after intestinal resection compared to omega-6 polyunsaturated fatty acids, suggesting that caution should be taken to use omega-3 fatty acids as adjuvants in the adaptive process after resection.

\section{INTRODUCTION}

In western countries, individuals consume 100-200 g fat per day, which corresponds to $35-45 \%$ of the dietary energy. Animal fat makes up $60-80 \%$ of the daily intake. The most important lipids in the human diet are triacylglycerols (TAGs). There is a wide variety of types of TAG-fatty acids consumed in the diet. The most abundant fatty acids consist of even number straight chains ranging from 4-carbon fatty acids in milk to 30-carbon fatty acids in some fish oils (Gunstone, Harwood, Padley, 1994).
The effects of composition and amount of fatty acids ingested by organisms have been studied for a long time. However, this interest has intensified in the last decades due to the demonstration that fatty acids play a very important role in the development of many diseases including cardiovascular disease and cancer (Landmark, 1998; Hubbard, Lim, Reickson, 1998). In almost all models studied the animals treated with omega- 6 polyunsaturated fatty acids showed a high incidence of tumors of increased size (Hillyard, Abraham, 1979; Connolly, Gilhooly, Rose, 1999), and of tumorigenesis (Wynder, 1987). In contrast, 
omega-3 fatty acids have opposite effects, i.e., they can inhibit cell division, cause cell cycle arrest, and induce cell death in malignant cells of various tissue origins in vitro (Mollerup, Haugen, 1996). In human beings, it was demonstrated that esters of the omega-3 fatty acids eicosapentaenoic acid (EPA) and docosapentaenoic acid (DHA) could reduce sporadic colonic adenomas (Anti et al., 1994). However, little is known about the effects of long-chain polyunsaturated fatty acids on normal epithelial cells.

The normal intestinal epithelium has a high cell turnover and extensive small bowel resection promotes structural, kinetic, and functional changes in the remaining intestine to allow the animal to adapt to the shortened intestine (Williamson, 1978). Increase in mucosal mass reaches a peak 7 to 12 days after intestinal resection (Hanson, Osborne, Sharp, 1977), and this compensatory response is more marked in the ileum than in the jejunum (Williamson, 1978). For this reason, in the present investigation we chose a period of 6 and 12 days after enterectomy to conduct our studies. A 50\% proximal resection was performed since it has been documented that the maximal increase in villus height is obtained after resection of $45 \%$ of the initial intestinal length and that after more extensive resection no further increment occurs (Menge, Robinson, 1978).

Thus, considering the high cellular turnover of the small bowel and its resection as a hyperproliferative physiological model, the present study was conducted to evaluate the effect of a fish oil concentrate (a source of EPA and DHA) in some intestinal mucosal parameters, such as specific enzymatic activities of disaccharidases (sucrase, lactase and maltase) and alkaline phosphatase, and DNA and TBARs (thiobarbituric acid reactive substances) levels before and after 50\% small bowel resection in normal rats receiving corn oil or fish oil for 15 days, and on the adaptation of the remnant intestinal epithelium after $50 \%$ proximal small bowel resection.

\section{MATERIAL AND METHODS}

The animals used in this study were maintained in accordance with the norms of the National Research Council (1996).

\section{Experimental design}

We used 52 male Wistar rats weighing 150-180 g obtained from the animal house of Ribeirão Preto Campus, University of São Paulo. The rats were allowed to adapt themselves to the local animal house conditions for 3 days before the experiment. They were housed individually in stainless steel wire-bottomed cages, and received a standard rat chow diet and water ad libitum during the acclimatization period, in a room with a $12 \mathrm{~h} \mathrm{light/dark} \mathrm{cycle,}$ at $25 \pm 1{ }^{\circ} \mathrm{C}$. The rats were randomly divided into two dietary groups and fed a modified AIN-93 chemically defined diet (Reeves, Nielsen, Fahey, 1993) containing 10\% (w/w) corn oil (control diet) or a fish oil concentrate (experimental diet). The latter was prepared to provide the required levels of essential fatty acids to the animals and contained $75 \%$ fish oil (equivalent to $16.8 \% \mathrm{EPA}$, and $6.3 \%$ DHA) plus $25 \%$ corn oil. Both diets were isonitrogen ( $10 \%$ casein, w/w) and isocaloric. Rats were fed with these diets for 2 weeks. The composition of oils used in our study is presented in Table I.

Six (6) rats from each group (corn oil and fish oil) were sacrificed under ether anesthesia, blood was collected by cardiac puncture and the serum was used for the determination of cholesterol and triglycerides.

The remaining 40 rats underwent a $50 \%$ resection of the proximal small bowel under ether anesthesia; $25 \%$ of the proximal bowel starting from the ligament of Treitz, and $25 \%$ of the distal bowel starting from the ileocecal valve were maintained. The intestine removed in the surgery was divided into two fragments named proximal jejunum and distal ileum. The fragments were carefully washed with cold $0.9 \%(\mathrm{w} / \mathrm{v}) \mathrm{NaCl}$, dried out with paper towels, and then opened longitudinally on a cold glass plate. The mucosa was scraped off with the help of glass slides, and frozen in liquid nitrogen. After surgery, the animals were given $5 \%(\mathrm{w} / \mathrm{v})$ glucose in $0.9 \%(\mathrm{w} / \mathrm{v}) \mathrm{NaCl}$ for the first 24 hours postoperatively, and then placed back on their respective study diets. Throughout the preoperative and postoperative period, food intake of both groups was measured daily and their weight gain weekly. The diets were previously prepared and stored in a freezer in tightly sealed plastic bags. The fish oil was added every day to prevent oxidation. The animals received fresh food every day.

The animals were killed 6 and 12 days after resection under superficial ether anesthesia. Blood was drawn by cardiac puncture at the time of sacrifice, and serum was obtained for the determination of triglycerides and cholesterol levels. Fragments of remnant jejunum and ileum were removed, and their mucosas were harvested as described above.

\section{Biochemical analysis}

Mucosal scrapings were homogenized in $2 \mathrm{mM}$ TrisHepes buffer, $\mathrm{pH} 7.0$, containing $100 \mathrm{mM}$ mannitol. The mucosal protein was determined by the method of 
TABLE I - Composition in fatty acids of oils used in diets. The data are presented as percentage.

\begin{tabular}{|c|c|c|c|}
\hline \multirow[t]{2}{*}{ Formula } & \multirow[t]{2}{*}{ Fatty acid } & \multicolumn{2}{|c|}{ Sample } \\
\hline & & Corn oil & Fish oil \\
\hline 08:0 & Caprylic acid & - & - \\
\hline 10:0 & Capric acid & - & - \\
\hline 12:0 & Lauric acid & - & - \\
\hline 14:0 & Myristic acid & - & $7.72 \pm 0.09$ \\
\hline 15:0 & Pentadecanoic acid & - & Traces \\
\hline 16:0 & Palmitic acid & $13.55 \pm 0.16$ & $16.16 \pm 0.69$ \\
\hline $16: 1$ & Palmitoleic acid & $0.13 \pm 0.01$ & $10.55 \pm 1.56$ \\
\hline $17: 0$ & Heptadecanoic acid & - & $1.25 \pm 0.00$ \\
\hline 18:0 & Stearic acid & $1.96 \pm 0.03$ & $2.65 \pm 0.04$ \\
\hline 18:1 & Oleic acid & $34.05 \pm 0.19$ & $17.03 \pm 1.08$ \\
\hline $18: 2$ & Linoleic acid & $48.83 \pm 0.08$ & $1.40 \pm 0.01$ \\
\hline $18: 3$ & Linolenic acid & $0.78 \pm 0.01$ & Traces \\
\hline $18: 4$ & Octadecatetraenoic acid & - & $1.96 \pm 0.04$ \\
\hline 20:0 & Arachidic acid & $0.52 \pm 0.01$ & - \\
\hline $20: 1$ & Eicosanoic acid & $0.21 \pm 0.03$ & $0.80 \pm 0.01$ \\
\hline $20: 4$ & Eicosatetraenoic acid & - & $1.50 \pm 0.14$ \\
\hline $20: 5$ & Eicosapentaenoic acid & - & $22.35 \pm 0.30$ \\
\hline $22: 0$ & Behenic acid & - & - \\
\hline $22: 1$ & Erucic acid & - & - \\
\hline $22: 5$ & Docosapentaenoic acid & - & $2.57 \pm 0.11$ \\
\hline $22: 6$ & Docosahexaenoic acid & - & $8.40 \pm 0.18$ \\
\hline \multirow[t]{4}{*}{$\mathrm{Ni}$} & Not identified & - & $5.70 \pm 0.57$ \\
\hline & Saturated & 16.03 & 27.78 \\
\hline & Unsaturated & 34.39 & 28.38 \\
\hline & Polyunsaturated & 49.61 & 38.18 \\
\hline
\end{tabular}

Fish oil: $22.35 \mathrm{~g}$ eicosapentaenoic acid $+8.40 \mathrm{~g}$ docosahexaenoic acid $=30.75 \mathrm{~g}$ omega- 3 fatty acids $/ 100 \mathrm{~g}$

Bensadoun and Weinsten (1976) and expressed as $\mathrm{mg}$ protein/g wet tissue. Mucosal DNA was extracted by serial precipitation with cold perchloric acid and assayed according to Burton (1956) as modified by Croft and Lubran (1965), using E. coli DNA as standard. DNA was expressed as $\mu \mathrm{g} / \mathrm{mg}$ protein. Mucosal disaccharidase activity was determined using sucrose, maltose and lactose as substrates by the method of Dahlqvist (1964), and expressed as nmol glucose liberated/mg protein/min. Mucosal alkaline phosphatase activity was determined using $p$-nitrophenylphosphate as substrate by the method of Murer et al. (1976), and expressed as nmol $p$-nitrophenyl liberated/mg protein/min. Leucine aminopeptidase activity was determined using L-leucyl-betanaphtylamide as substrate; the color was developed as described by Goldbarg, Pineda, Rutemberg (1959), and enzymatic activity was expressed as $\mu$ mol betanaphtylamine liberated/mg protein/min. TBARs were determined by the method of Buege and Aust (1978), and expressed as nmol TBARs/mg protein. Cholesterol and triglyceride levels were determined by an enzymatic method using a commercial kit from Labtest (São Paulo, Brazil).

\section{Statistical analysis}

All data were reported as arithmetic mean \pm SEM and analysed by analysis of variance with the level of significance set at 5\%. The significant differences among means were further analysed by the Duncan test.

\section{RESULTS}

There were no differences in diet ingestion or body weight between the two dietary groups during preoperative and postoperative periods (data not shown). Triglyceride levels were reduced but not significantly so in the fish oil-fed group and cholesterol levels presented any differences among groups (Figure 1). 


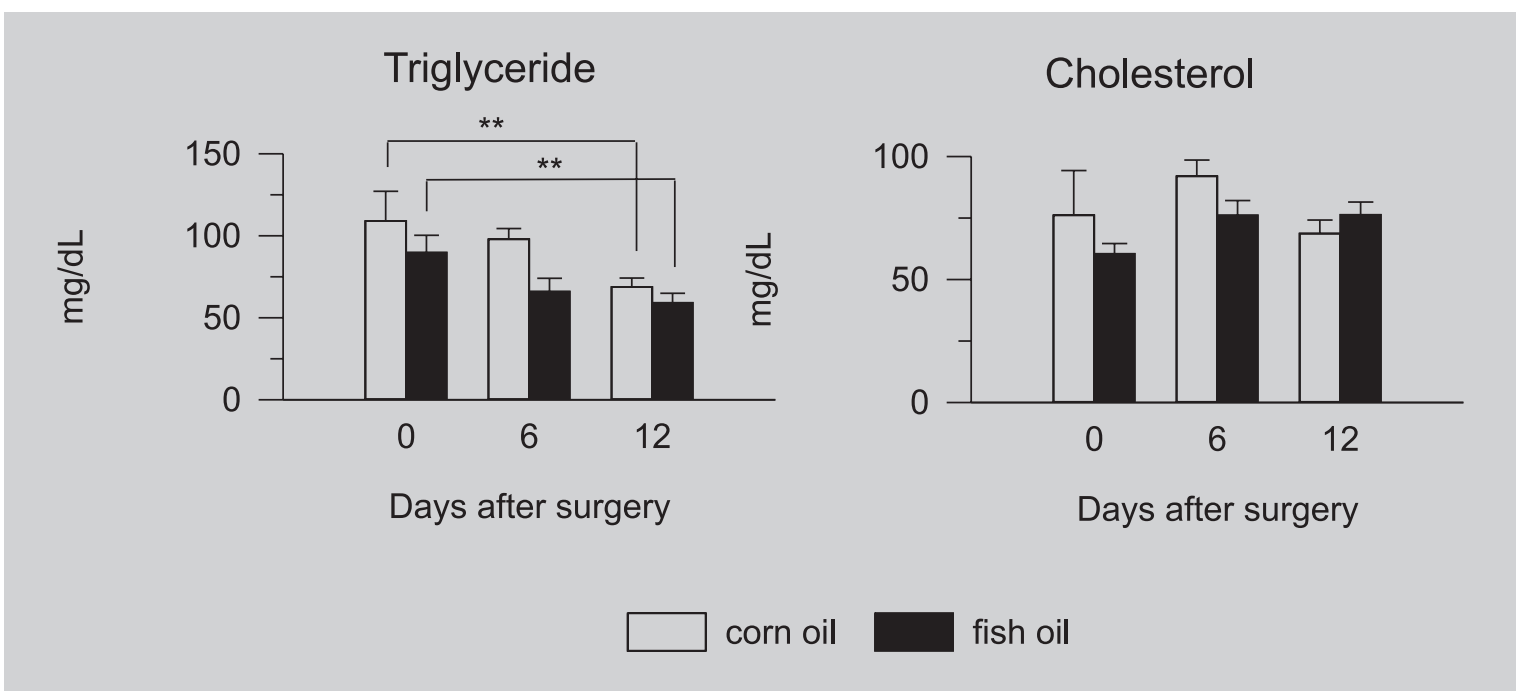

FIGURE 1 - Serum triglyceride and cholesterol levels in animals before and after 50\% proximal bowel resection. * corresponds to a significant difference between diets; $* *$ correspond to a significant difference compared to day 0 , in same diet. ( $\mathrm{n}=6$ rats for 0 day end $8-12$ rats for each period).

Enzyme specific activities in the ileal mucosa are shown in Figure 2 and protein, DNA, and TBARs levels in Figure 3. After 15 day pre-treatment with the two diets, the jejunal mucosa from animals fed corn oil or fish oil showed no differences between diets in enzyme specific activities or protein, DNA and TBARs levels (data not shown). In the ileum, mucosal disaccharidase (sucrase, lactase and maltase - the latter two activities were not shown in the figure, because they presented the same profile as sucrase) specific activities were reduced significantly in the animals fed fish oil (indicated by * in the figure) and alkaline phosphatase and aminopeptidase specific activities did not show any differences between corn oil or fish oil based diets (Figure 2).

In the remnant ileum, the differences in disaccharidase specific activities observed during the preoperative period in animals fed fish oil were maintained after resection. The alkaline phosphatase specific activity of animals fed corn oil was significantly reduced on the $6^{\text {th }}$ postoperative day and increased on the $12^{\text {th }}$ postoperative day (indicated by $* *$ in the figure). Animals fed fish oil showed no alterations in ileal mucosal alkaline phosphatase specific activity and on the $12^{\text {th }}$ postoperative day differences among diets were significant (Figure 2, indicated by *).

There were no differences between groups or experimental periods in aminopeptidase specific activity (Figure 2 ) and protein, TBARS or DNA levels (Figure 3).

\section{DISCUSSION}

It has been described that rats treated with fish oil tend to spill food (Halminski, Marsh, Harrison, 1991). This was not observed in the present study, and no differences were detected in average weight gain between the two dietary groups during preoperative or postoperative periods. The triglyceride levels were reduced but not so significantly in the fish oil-fed group, in agreement with the results reported by Rabbani et al. (2001). Cholesterol levels presented no differences among groups, in contrast to the data reported by Rabbani et al. (2001), who observed reduced cholesterol levels in rats treated with high doses of fish oil ( $5 \mathrm{ml}$ of fish oil $/ \mathrm{kg} /$ day). This difference could probably be attributed to the lower amount of fish oil ingested by the rats in our study.

In the present study lactase, maltase and sucrase specific activities measured in ileal mucosa homogenates were reduced in the group that received fish oil for 15 days before enterectomy. Our results were similar to those reported by Kaur et al. (1996), who demonstrated a reduction of leucine aminopeptidase and sucrase activity in the ileum from rats fed fish oil for 5 weeks. However, Vanderhoof et al. (1994), after feeding normal rats with a chemically defined diet containing $15 \%$ menhaden oil for 4 weeks, did not observe these effects. Also, the authors did not report the composition of the menhaden oil used in their study. Although we have used a lower calorie content in fat than Vanderhoof et al. (1994), 23\% vs. 30\% energy as fat, respectively, the fish oil used in our study was enriched with EPA and DHA. Thus, our results could be probably attributed to high different relative proportions of EPA and DHA in fish oil used in our experiments. Additionally, we used the same proportion of fish oil as used 


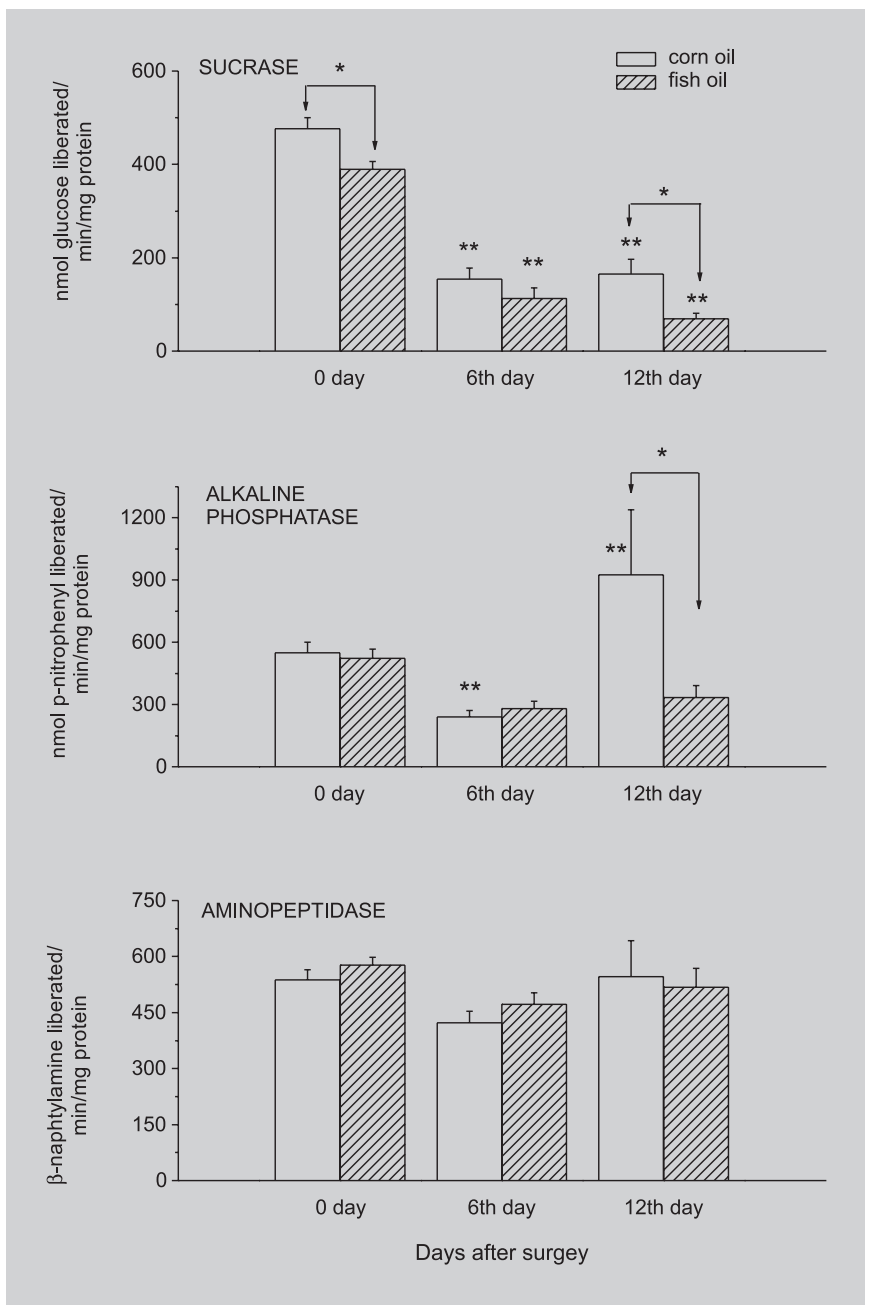

FIGURE 2 - Effect of dietary fish oil on mucosal disaccharidase, alkaline phosphatase, and aminopeptidase specific activities before and after $50 \%$ proximal bowel resection. * corresponds to a significant difference between diets; $* *$ correspond to a significant difference compared to day 0 , in same diet. ( $\mathrm{n}=20$ rats for 0 day; 8 12 rats for $6^{\text {th }}$ and $12^{\text {th }}$ days).

by Deschner et al. (1990), who observed prevention of the development of an adenoma-type proliferative pattern in chemically induced cancer in rats fed fish oil.

The reduction of disaccharidase specific activity in normal ileal mucosa and no effect in normal jejunal mucosa in the group fed fish oil could be due to a higher absorption of fatty acids in the ileum than in the jejunum (Chen et al., 1995).

The levels of sucrase activity are considered as a marker of enterocyte maturation (Ferretti et al., 1996). The difference in ileal disaccharidase activity between two fatty acid groups was observed before and on the $12^{\text {th }}$ day post operation. Thus, these differences may have not been

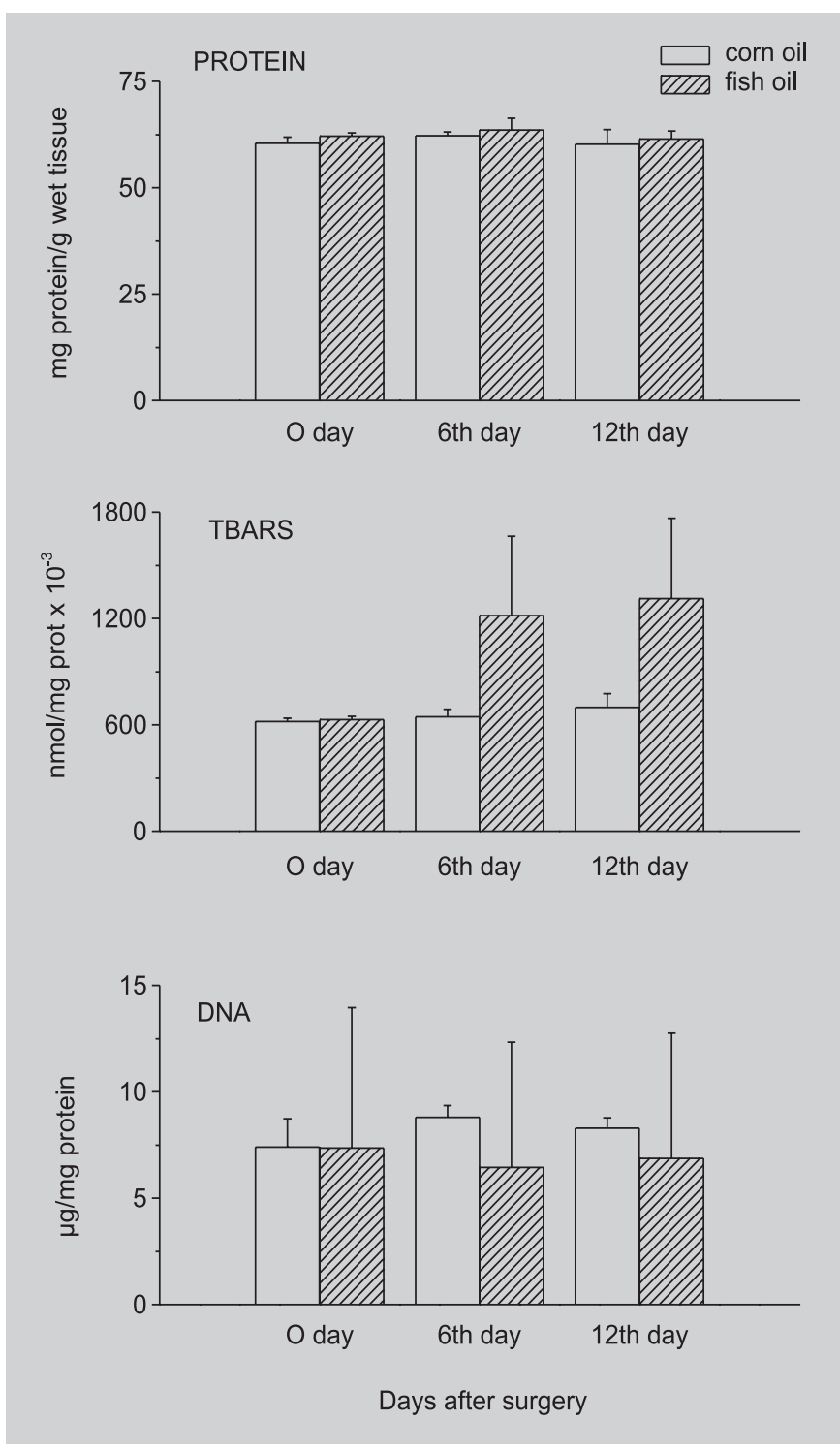

FIGURE 3 - Effect of dietary fish oil on mucosal protein, DNA and TBARS levels before and after 50\% proximal bowel resection.

due only to resection since we observed no differences in protein or DNA levels. The reduction observed in our study could be interpreted as a specific adaptive response to the effect of dietary fish oil on growth rate, probably timing the growth curve of enterocyte differentiation (Smith, 1985). If dietary fish oil alter some aspects of enterocyte migration and/or differentiation from crypt to villus tip, the disaccharidases will be more affected than alkaline phosphatase, because these enzymes become well expressed soon after movement of the cell from crypt to villus, and alkaline phosphatase (Albert, Young, 1992) and aminopeptidase (King et al., 1981) are specifically expressed by cells at the villus tip. Thus, while cells were 
able to express a normal level of alkaline phosphatase or aminopeptidase in both groups (corn oil and fish oil), they were unable to express disaccharidases fully in the fish oilfed group because of the reduction of differentiation process promoted by fish oil. It is possible that over a long period of time the full enterocyte differentiation process could be attained in the fish oil-fed group. However, cellular differentiation is a very complex process and should not be analyzed only on the basis of reduction in disaccharidase activity.

In our study, alkaline phosphatase specific activity was increased only in the control group (corn oil) 12 days after resection. It has been reported that the interactions of protein and lipids of the intestinal microvillus membrane can influence protein function. Enzymes such as lactase, maltase, sucrase, leucine-aminopeptidase and gamma-glutamyl transpeptidase do not appear to experience functionally the effects of lipid composition. Instead, alkaline phosphatase is an integral enzyme, intimately associated with the hydrophobic core of the intestinal microvillus membrane (Brasitus et al., 1979, 1988) and can be affected by the lipid environment. Thus, it is reasonable to suggest that the reduced expression of this enzyme in the group fed fish oil observed in our study may have been caused in part by alterations of the membrane lipid composition. Additionally, Wahnon, Coogan, Mokady (1992) described a reduction of alkaline phosphatase in isolated intestinal brush border vesicles from rats fed $15 \%$ fish oil, with no effect on the lipid fluidity of intestinal microvilli.

The differential response of enzymes (reduction of sucrase and no effect on alkaline phosphatase) in normal and hyperplastic and hypertrophic ileal mucosa to dietary fish oil observed in the present study suggests a reduction on the process of enterocyte differentiation process and on the intestinal adaptation to resection. This finding suggests that caution should be taken in using polyunsaturated fatty acids, especially omega-3 fatty acids, as therapeutical adjuvants in the treatment of intestinal resection.

\section{RESUMO}

\section{Efeito do ácido graxo ômega-3 no intestino delga- do de ratos antes e após ressecção}

No presente estudo, foi avaliado o efeito da dieta com óleo de peixe, uma fonte de ácidos graxos altamente insaturados, sobre a mucosa intestinal antes e após resecção do intestino delgado proximal em ratos. Quarenta ratos Wistar foram alimentados com dieta definida contendo óleo de peixe (grupo experimental) ou óleo de milho (grupo controle). Após duas semanas, os animais foram submetidos à ressecção de $50 \%$ do intestino delgado proximal. Os níveis das dissacaridases, fosfatase alcalina, animopeptidade, proteina, DNA e TBARS foram avaliados, imediatamente antes e 6 e 12 dias após a cirurgia. As atividades das dissacaridases foram reduzidas na mucosa ileal no grupo de ratos alimentados com óleo de peixe, comparado com grupo controle antes e 12 dias após a cirurgia. Os outros parâmetros não mostraram diferenças significativas. Este resultado indica que o óleo de peixe (ácidos graxos ômega-3) altera parâmetros funcionais na mucosa intestinal normal e após resecção, comparado ao ácido graxo ômega-6, sugerindo cautela no uso de ácidos graxos ômega-3 como adjuvante no processo adaptativo após resecção.

UNITERMOS: Ácidos graxos poliinsaturados ômega3. Ressecção intestinal. Adaptação intestinal.

\section{ACKNOWLEDGMENTS}

The authors would like to thank Mr. Sebastião Assis Mazzetto (Departamento de Cirurgia, Faculdade de Medicina de Ribeirão Preto, Universidade de São Paulo) for expert technical assistance in rat surgery, and M. Laura M. Kawasse and Marcia A. Destido (Departamento de Patologia, Faculdade de Medicina de Ribeirão Preto, Universidade de São Paulo) for expert technical assistance with the histological preparations. This work was supported by Fundação de Amparo à Pesquisa do Estado de São Paulo, FAPESP (grant no. 98/12388-1 and fellowship no. 98/ 12376-3) and Pronex/CNPq (grant no. 661132/98-6).

\section{REFERENCES}

ALBERT, V.; YOUNG, G.P. Differentiation status of rat enterocytes after intestinal adaptation to jejunoileal bypass. Gut, London, v.33, n.12, p.1638-1643, 1992.

ANTI, M.; ARMELAO, F.; MARRA, G.; PERCESEPE, A.; BARTOLI, G.M.; PALOZZA, P.; PARRELA, P.; CANETTA, C.; GENTILONI, G.M.; DE VIOTIS, I.; GASBARRINI, G. Effect of different doses of fish oil on rectal cell proliferation in patients with sporadic colonic adenomas. Gastroenterology, Philadelphia, v.104, n.6, p.1709-1718, 1994.

BENSADOUN, A.; WEINTEIN, D. Assay of proteins in the presence of interfering materials. Anal. Biochem., San Diego, v.70, n.1, p.241-250, 1976. 
BRASITUS, T. A.; SCHACHTER, D.; MAMOUNEAS, T. G. Functional interactions of lipids and proteins in rat intestinal microvillus membranes. Biochemistry, Washington, v.18, n.19, p.4136-4144, 1979.

BRASITUS, T.A.; DAHIYA, R.; DUDEJA, P.; BISSONNETTE, B.M. Cholesterol modulates alkaline phosphatase activity of rat intestinal microvillus membranes. J. Biol. Chem., Bethesda, v.263, n.18, p.8592-8597, 1988.

BUEGE, J.; AUST, S.D.G. Mucosal lipd peroxidation. Meth. Enzymol., v.52, p.302-310, 1978.

BURTON, K. Study of the conditions and mechanism of diphenylamine reaction for the colorimetric estimation of deoxyribonucleic acid. Biochem. J., London, v.62, n.2, p. 315-323, 1956.

CHEN, W.J.; YANG, C.L.; LAY, H.S, CHEN, K.M. Effects of lipids on intestinal adaptation following $60 \%$ resection in rats. J. Surg. Res., San Diego, v.58, n.3, p.253-295, 1995.

CROFT, D.M.; LUBRAN, M. The estimation of deoxyribonucleic acid in the presence of sialic acid: application to analysis of human gastric washings. Biochem. J., London, v. 95, n.3, p.612-620, 1965.

DAHLQVIST,A. Method for assay of intestinal disaccharidases. Anal. Biochem., San Diego, v.7, n.1, p.18-25, 1964.

DESCHNER, E.E.; LYTLE, J.S.; WONG, G.; RUPERTO, J.F.; NEWMARK, H.L. The effect of dietary omega-3 fatty acids (fish oil) on azoxymethane-induced focal areas of dysplasia and colon tumor incidence. Cancer, New York, v.66, n.11, p.2350-2356, 1990.

FERRETTI, E.; LI, S.; WANG, J.Y.; POST, M.; MOORE, A. Mesenchymal regulation of differentiation of intestinal epithelial cells. J. Pediatr. Gastroenterol. Nutr., Philadelphia, v.23, n.1, p.65-73, 1996.

GOLDBARG, J.A.; PINEDA, E.P.; RUTEMBERG, A.M. The measurement of activity of leucine aminopeptidase in serum, urine, bile and tissues. Am. J. Clin. Pathol., Chicago, v.32, n.6, p.571-575, 1959.

GUNSTONE, F.; HARWOOD, J.L.; PADLEY, F.B. The Lipid Handbook. $2^{\text {nd }}$ ed. London: Chapman and Hall, 1994, p. 47-208.
HALMINSKI, M.A.; MARSH, J.B.; HARRISON, E.H. Differential effects of fish oil, safflower oil and palm oil on fatty acids oxidation and glycerolipid synthesis in rat liver. J. Nutr., Philadelphia, v.121, n.10, p.1554-1561, 1991.

HANSON, W.R.; OSBORNE, J.W.; SHARP, J.G. Compensation by the residual intestine after intestine resection in the rat. II - Influence of postoperative time interval. Gastroenterology, Philadelphia, v.72,n.4, p.701-705, 1977.

HILLYARD, L.A.; ABRAHAM, S. Effect of dietary polyunsatured fatty acids on growth of mammary adenocarcinomas in mice and rats. Cancer Res., Philadelphia, v.39, n. 11, p.4430-4437, 1979.

HUBBARD, N.E.; LIM, D.; REICKSON, K.L. Alteration of murine mammary tumorigenesis by dietary enrichment with n-3 fatty acid in fish oil. Cancer. Lett., Clare, v.124, n.1, p.1-7, 1998.

KAUR, M.; KAUR, J.; OJHA, S.; MAHAMOOD, A. Dietary fat effects on brush border membrane composition and enzyme activities in rat intestine. Ann. Nutr. Metab., Basel, v.40, n.5, p.269-276, 1996.

KING, I.S.; PATERSON, J.Y.F.; PEACOCK, M.A.; SMITH, M.W.; SYME, G. Effect of diet upon enterocyte differentiation in the rat jejunum. J. Physiol - London, New York, v.344, p.465-481, 1983.

LANDMARK, K.; ABDELNOOR, M.; URDAL, P.; KILHOVD, B.; DORUM, H.P.; BORGE, N.; REFVEM, H. Use of fish oils appears to reduce infarct size as estimated from peak creatine kinase and lactate dehydrogenase activities. Cardiology, Basel, v.89, n.2, p.94-102, 1998.

MENGE, H.; ROBINSON, J.W.L. Relationship between the functional and structural alteration in the rat small intestine following proximal resection of varying extents. Res. Exp. Med., New York, v.73, n.1, p.41-53, 1978.

MOLLERUP, S.; HAUGEN, A. Differential effect of polyunsaturated fatty acids in cell proliferation during human epithelial in vitro carcinogenesis: involvement of epidermal growth factor receptor tyrosine kinase. $\mathrm{Br} . J$. Cancer, Hampshire, v.74, n.4, p.613-618, 1996.

MURER, H.; AMMANN, E.; BIBER, J.; HOPFFER, U. Surface membrane of the small intestine epithelial cell. Localization of adenyl cyclase. Biochem. Biophys. Acta, Amsterdam, v.433, n.3, p.509-519, 1976. 
NATIONAL RESEARCH COUNCIL. Institute of Laboratory Animal Resources. Guide for the care and use of laboratory animals. Washington: National Academy Press, 1996. p. 125

RABBANI, P.I.; ALAN, H.Z.; CHIRTEL, S.J.; DERVALL, R.E.; JACKSON, R.C.; RUFFIN, G. Subchronic toxicity of fish oil concentrates in male and female rats. J. Nutr. Sci. Vitaminol., Tokyo, v.47, n.3, p.201-212, 2001.

REEVES, P.G.; NIELSEN, F.H.; Jr FAHEY, G.C. AIN-93 purified diets for laboratory rodents: final report of the American Institute of Nutrition ad hoc writing committee on the reformulation of the AIN-76A rodent diet. J. Nutr., Bethesda, v.123, n.11, p.1939-1951, 1993.

SMITH, M.W. Expression of digestive and absorptive function in differentiating enterocytes. Ann. Rev. Physiol., Palo Alto, v.47, p.247-260, 1985.
VANDERHOOF, J.A.; PARK, J.H.Y.; HERRINGTON, M.K.; ADRIAN, T.E. Effects of dietary menhaden oil on mucosal adaptation after small bowel resection in the rat. Gastroenterology, Philadelphia, v.106, n.1, p.94-99, 1994.

WAHNON, R.; COOGAN, V.; MOKADY, S. Dietary fish oil modulates the alkaline phosphatase activity and not the fluidity of rat intestinal microvillus membrane. J. Nutr., Bethesda, v.122, n.5, p.1077-1084, 1992.

WILLIAMSON, R.C.N. Intestinal adaptation.1. Structural, functional and cytokinetic changes. N. Engl. J. Med., Boston, v.298, n.25, p.1393-1402, 1978.

WYNDER, E.L. Amount and type of fat/fiber in nutritional carcinogenesis. Prev. Med., San Diego, v.16, n.4, p.451459, 1987.

Recebido para publicação em 11 de maio de 2004. Aceito para publicação em 27 de janeiro de 2005. 